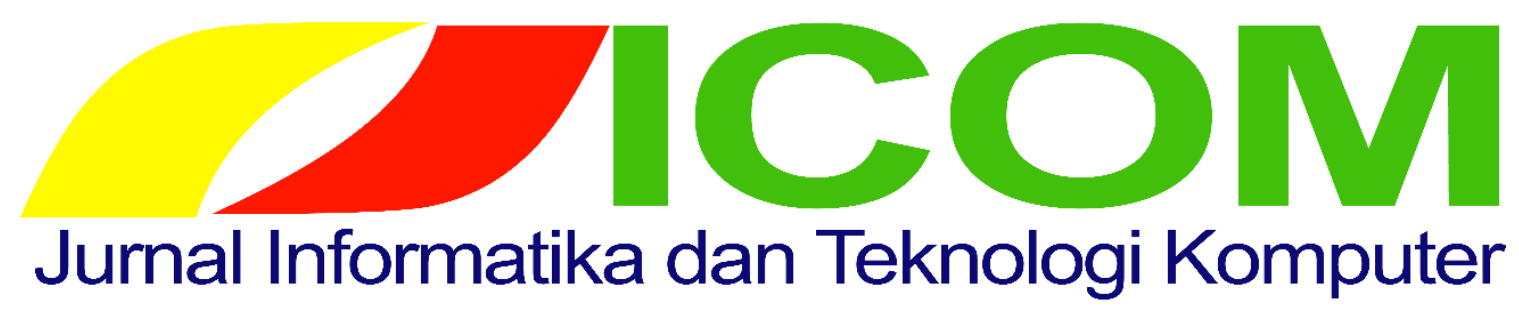

Vol. 02 No. 01 (2021) $17-22$

E-ISSN :2774-7115 P-ISSN: 2775-2089

\title{
SISTEM INFORMASI CUTI PEGAWAI DI BADAN PUSAT STATISTIK KOTA LANGSA
}

\author{
${ }^{1 *}$ Novianda, Seri Rati², Rizalul Akram ${ }^{3}$ \\ ${ }^{1}$ Teknik Informatika, Teknik, Universitas Samudra \\ ${ }^{2}$ Teknik Informatika, Teknik, Universitas Samudra \\ ${ }^{3}$ Teknik Informatika, Teknik, Universitas Samudra \\ 1*novianda_tif@unsam.ac.id, ${ }^{2}$ seriratih05@gmail.com ${ }^{3}$ rizalulakram@unsam.ac.id
}

\begin{abstract}
Limitations regarding the process of applying for employee leave at the Central Bureau of Statistics in Langsa City tend to be ineffective and efficient, so that in the process it makes both employees and leaders feel difficult. In addition to the piles of leave submission files, sometimes forget to process them when an employee applies for leave. The research objective is to produce a web-based leave application program so as to provide convenience to users in applying for and processing leave without always repeating data entry due to operational difficulties. In addition, the time needed is faster and the data entered is more accurate.
\end{abstract}

Keywords: Information Systems, PHP, MYSQL, Employees, Leave

\begin{abstract}
Abstrak
Keterbatasan mengenai proses pengajuan cuti pegawai di Badan Pusat Statistik Kota Langsa cenderung tidak efektif dan efisien sehingga dalam prosesnya tersebut membuat kedua belah pihak pegawai dan pimpinan merasa kesulitan. Selain berkas pengajuan cuti yang betumpuk, terkadang lupa untuk memperoses ketika ada pegawai yang mengajukan cuti. Tujuan penelitian menghasilkan program pengajuan cuti berbasis web sehingga memberikan kemudahan kepada pengguna dalam mengajukan dan memperoses cuti tanpa selalu mengulang mengisikan data karena kesulitan pengoperasian. Selain itu waktu yang dibutuhkan lebih cepat dan data yang diisikan lebih akurat.
\end{abstract}

Kata Kunci: Sistem Informasi, PHP, MYSQL, Pegawai, Cuti

\section{Pendahuluan}

Dengan adanya komputer yang terus berkembang sampai saat ini memberikan keuntungan lebih bagi perusahaan untuk melaksanakan kegiatannya, karena ada beberapa pekerjaan menjadi lebih mudah dan hemat waktu dengan menggunakan komputer contoh sederhana seperti mengetik surat menggunakan komputer, membuat form tabel dan lainnya. Perkembangan komputer tersebut diiringi dengan perkembangan aplikasi - aplikasi yang dibuat dengan tujuan untuk memudahkan pekerjaan dalam perusahaan. Dengan perpaduan perkembangan tersebut beberapa kegiatan bisnis dalam perusahaan dapat dibuat secara tersistem. Instansi pemerintah BPS (Badan Pusat Statistik) Langsa salah satunya yang menjadikan komputer sebagai suatu kebutuhan dalam melakukan pekerjaannya, seperti halnya cuti pegawai yang diperlukan adanya sistem dalam pengelolaan cuti.

Cuti adalah keadaan tidak masuk kerja yang diizinkan dalam jangka waktu tertentu. Atau dapat juga merupakan hak bagi Negeri Sipil berupa izin tidak masuk kerja yang dapat ditunda dalam jangka waktu tertentu apabila kepentingan dinas mendesak. 
Cuti merupakan salah satu kebijakan perusahaan yang menjadi favorit para karyawan. Jatah cuti biasanya sering diambil para karyawan untuk melakukan hal-hal pribadi seperti berlibur, mengunjungi orang tua dan lain-lain. (Negara, 2017)

Cuti di kantor Badan Pusat Statistik cenderung tidak efektif sehingga membuat waktu pengisian data berjalan lama dan itu mengakibatkan deadline cuti tidak tepat waktu dan olah data menjadi kacau. Dengan demikian diperlukan sistem informasi cuti Pegawai di kantor Badan Pusat Statistik. Dengan adanya pengembangan sistem informasi yang baik, maka akan lebih memudahkan bagi user untuk mengoperasikan sistem informasi yaitu tanpa selalu mengulang mengisikan data karena kesulitan pengoperasian. Selain itu waktu yang dibutuhkan lebi cepat dan data yang diisikan lebih akurat.

\section{Rancang Sistem dan Analisis \\ 1.1 DFD (Data Flow Diagram)}

DFD atau Data Flow Diagram digunakan dalam penyajian alur dari sebuah sistem yang manual maupun otomatis. DFD terdiri dari Diagram Konteks, DFD Level 0 dan DFD Level 1.

\subsubsection{Diagram Konteks}

Adapun perancangan sistem informasi cuti Pegawai digambarkan melalui diagram konteks. Pada Diagram ini hanya terlihat input dan output dari sebuah sistem yang akan dibangun. Diagram konteks yang terdapat pada gambar 4.2 menggambarkan dasar dari perancangan sistem informasi cuti Pegawai berbasis web. Pada aplikasi ini admin dapat melakukan pengelolaan data karyawan, data pimpinan, jenis cuti, setting cuti, data karyawan cuti. Kemudian Karyawan melakukan login, permohonan cuti dan dapat melihat data cuti. Pimpinan dapat melihat data karyawan, permohonan cuti dan persetujuan cuti. Adapun bentuk diagram konteks dapat dilihat pada gambar berikut.

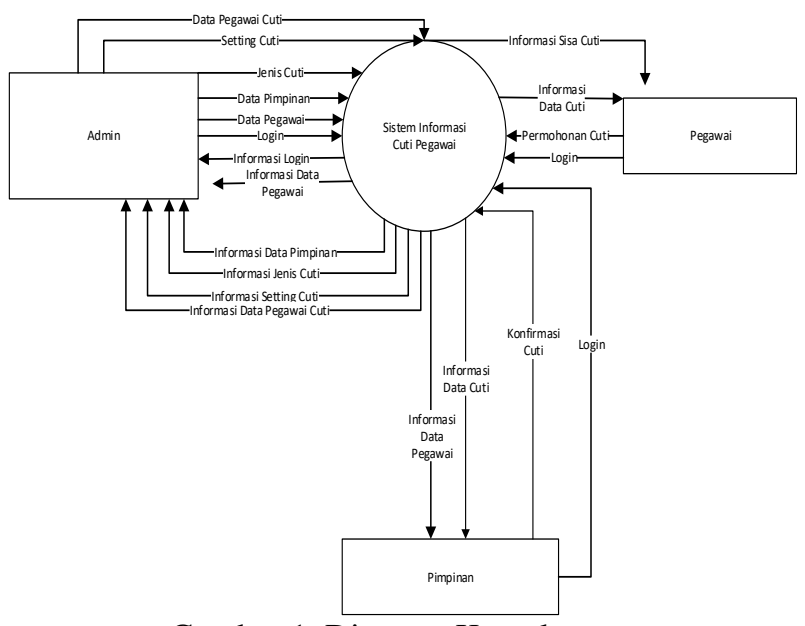

Gambar 1. Diagram Konteks

\subsubsection{DFD Level}

DFD Level 0 merupakan pemecahan dari diagram konteks. Pada gambar DFD Level 0 terdapat beberapa proses yaitu proses login, pengelolaan data pegawai, data permohonan cuti dan data cuti. Dimana Admin perlu melakukan Login terlebih dahulu sehingga Admin dapat masuk ke sistem untuk melakukan proses kelola data seperti insert data, delete maupun edit data. Kemudian pegawai melakukan permohonan cuti ke pemimpin. Pimpinan dapat menyetujui cuti dan melihat laporan cuti pegawai. Adapun bentuk DFD level 0 dapat dilihat pada gambar berikut.

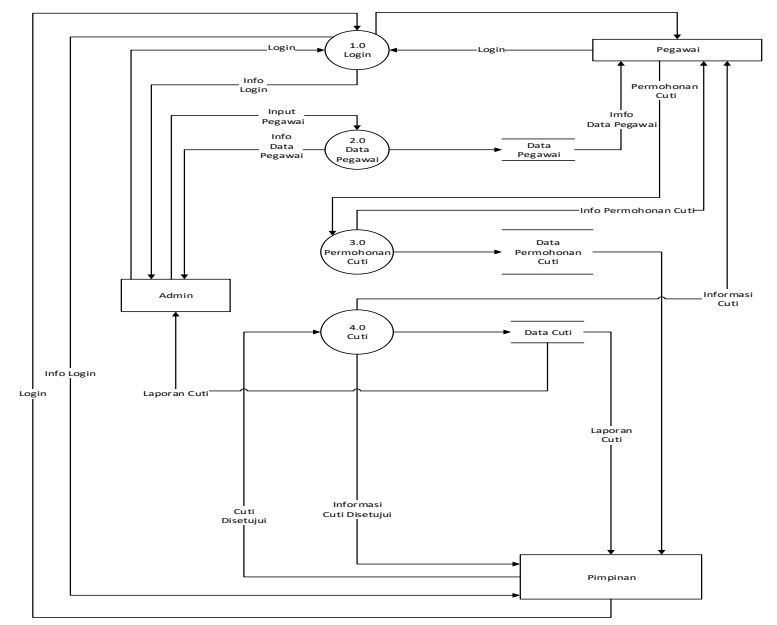

Gambar 2. DFD Level 0

\subsubsection{DFD Level 1}

DFD Level 1 merupakan tabel dari data pegawai, dimana admin memasukkan data pegawai cuti, kemudian pegawai dapat melihat data yang diisi oleh admin. Pimpinan dapat melihat informasi data-data cuti. Adapun bentuk DFD level 1 dapat dilihat sebagai berikut. 


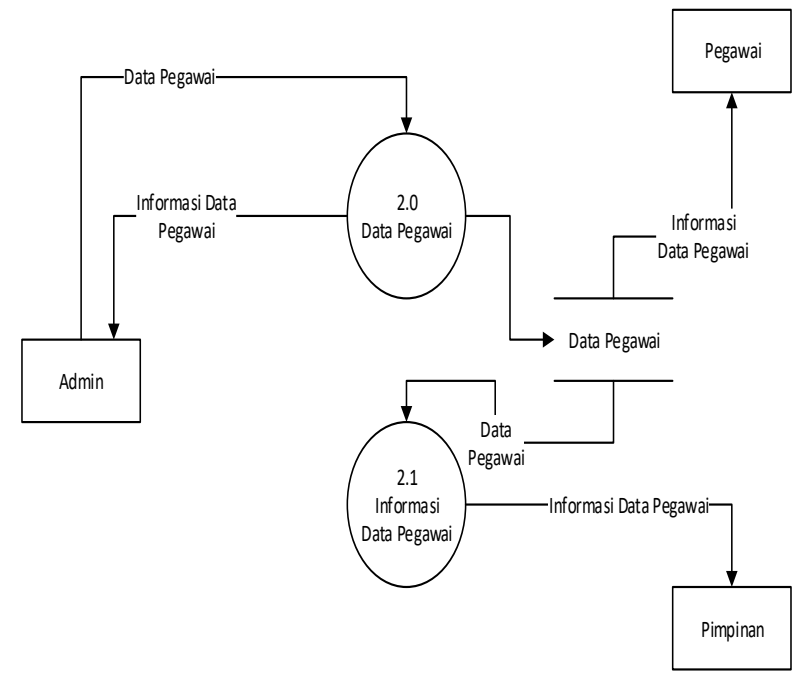

Gambar 3. DFD level 1

\subsubsection{DFD Level 2}

DFD Level 2 merupakan tabel dari permohonan cuti, dimana pegawai melakukan permohonan cuti kepimpinan, pimpinan akan menyetujui atau menolak cuti yang diajukan pegawai, kemudian pimpinan dapat melihat data cuti pegawai. Adapun bentuk DFD level 2 dapat dilihat sebagai berikut.

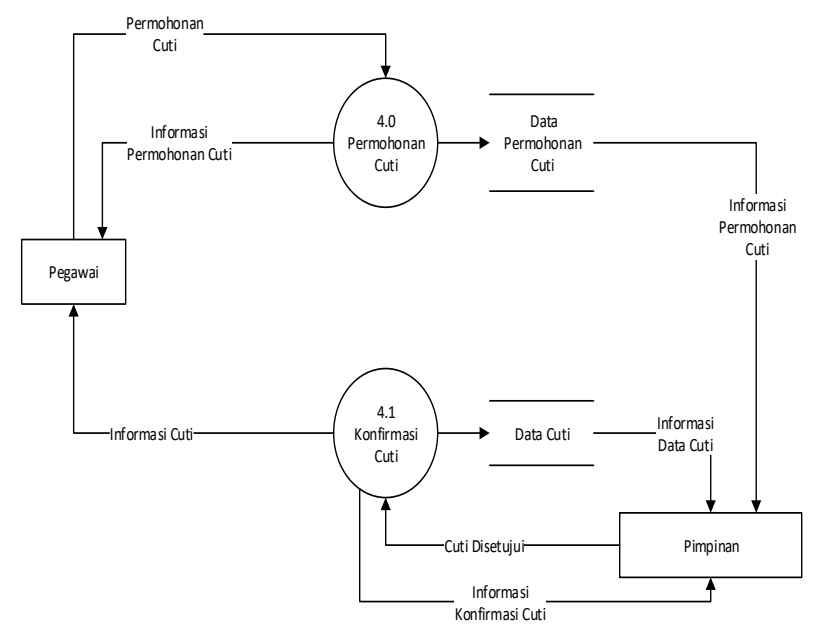

Gambar 4. DFD level 2

\subsection{ERD (Entity Relationship Diagram)}

Pada ERD terdapat tiga user yaitu admin, pegawai dan pimpinan. Admin dengan primary key id_admin menginput data pegawai. data pegawai yang memiliki primary key id_pegawai dan foreign key nip to id memilih jenis cuti yang memiliki primary key id_cuti kemudian mengajukan permohonan cuti yang memiliki primary key id dan foreign key nip to $\underline{\text { id }} \mathrm{ke}$ pimpinan,. Kemudian pimpinan menindak lanjuti permohonan cuti pegawai. Adapun relasi dan entitas-entitas pada diagram adalah admin one to many melakukan setting cuti. admin one to many dengan pegawai. Pegawai one to money memilih jenis cuti, pegawai one to many mengajukan permohonan cuti ke pimpinan.

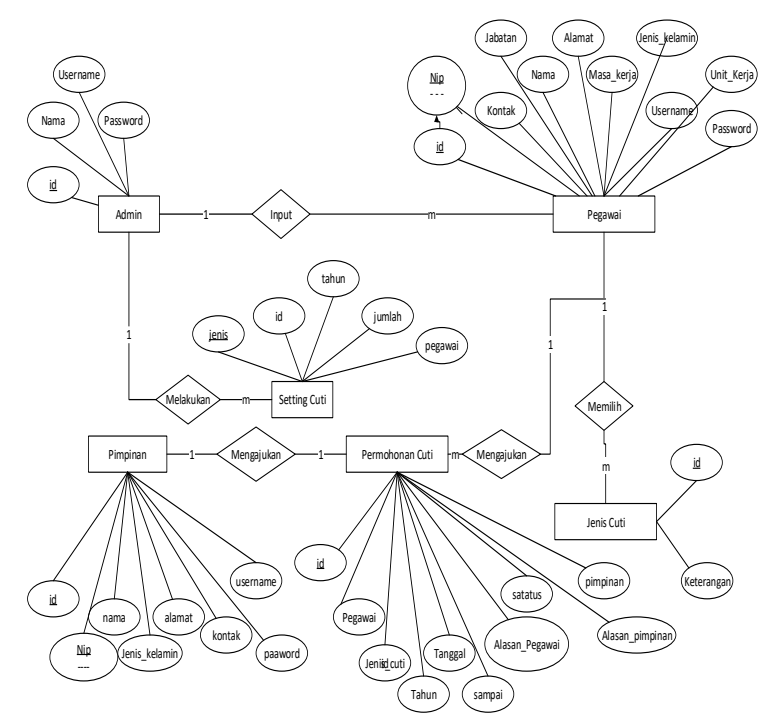

Gambar 5. ERD

\subsection{Desain Database}

Dalam merancang sebuah sistem yang baik diperlukan beberapa file yang bertujuan untuk mempermudah pengambilan data berupa informasi. File-file tersebut akan sama-sama terhubung antara satu dengan yang lain dan bisa digunakan sesuai dengan keperluan programmer ataupun pemakai (user). Tabel-tabel tersebut antara lain:

a. Desain Tabel Admin

Tabel 1 Perancangan Tabel Admin

\begin{tabular}{|l|l|l|c|l|}
\hline NO & Filed Name & Data Type & $\begin{array}{c}\text { Field } \\
\text { Size }\end{array}$ & Keterangan \\
\hline 1. & Id & Integer & 50 & Id admin \\
\hline 2. & Nama & Varchar & 50 & Email admin \\
\hline 3. & Username & Varchar & 50 & $\begin{array}{l}\text { Username } \\
\text { admin }\end{array}$ \\
\hline 4. & Password & Varchar & 50 & $\begin{array}{l}\text { Password } \\
\text { admin }\end{array}$ \\
\hline
\end{tabular}

b. Desain Tabel Pegawai

Tabel 2 Perancangan Tabel Pegawai

\begin{tabular}{|c|l|l|c|l|}
\hline NO & Filed Name & Data Type & $\begin{array}{c}\text { Field } \\
\text { Size }\end{array}$ & Keterangan \\
\hline 1 & Id & Integer & 11 & Id Pegawai \\
\hline 2 & Nip & Integer & 20 & Nip Pegawai \\
\hline 3 & Nama & Varchar & 50 & $\begin{array}{l}\text { Nama } \\
\text { Pegawai }\end{array}$ \\
\hline 4 & Alamat & Varchar & 50 & $\begin{array}{l}\text { Alamat } \\
\text { Pegawai }\end{array}$ \\
\hline 5 & Kelamin & Varchar & 50 & $\begin{array}{l}\text { Kelamin } \\
\text { Pegawai }\end{array}$ \\
\hline 6 & Kontak & Varchar & 50 & $\begin{array}{l}\text { Kontak } \\
\text { Pegawai }\end{array}$ \\
\hline
\end{tabular}

Diterima Redaksi : 12-03-2021 | Selesai Revisi : 29-03-2021 | Diterbitkan Online : 01-04-2021 
Novianda ${ }^{1}$, Seri Rati ${ }^{2}$, Rizalul Akram ${ }^{3}$

Jurnal J-COM (Jurnal Informatika dan Teknologi Komputer) Vol. 02 No. 01 (2021) 17 - 22

\begin{tabular}{|c|l|l|c|l|}
\hline 7 & Jabatan & Varchar & 50 & $\begin{array}{l}\text { Jabatan } \\
\text { Pegawai }\end{array}$ \\
\hline 8 & $\begin{array}{l}\text { Unit } \\
\text { Kerja }\end{array}$ & Varchar & 50 & $\begin{array}{l}\text { Unit } \\
\text { Kerja } \\
\text { Pegawai }\end{array}$ \\
\hline 9 & $\begin{array}{l}\text { Masa } \\
\text { Kerja }\end{array}$ & Varchar & 50 & $\begin{array}{l}\text { Masa } \\
\text { Kerja } \\
\text { Pegawai }\end{array}$ \\
\hline 10 & Username & Varchar & 50 & $\begin{array}{l}\text { Username } \\
\text { Pegawai }\end{array}$ \\
\hline 11 & Password & Varchar & 50 & $\begin{array}{l}\text { Password } \\
\text { Pegawai }\end{array}$ \\
\hline
\end{tabular}

\begin{tabular}{|l|l|l|l|l|}
\hline 4. & Pegawai & Integer & 11 & Pegawai \\
\hline 5. & Jumlah & Integer & 11 & $\begin{array}{l}\text { Jumlah } \\
\text { Cuti }\end{array}$ \\
\hline
\end{tabular}

\section{Hasil Dan Pembahasan}

2.1 From Login Admin

Sebelum menjalankan program, terlebih dahulu masuk ke form login. Pada form login admin harus mengisikan username dan password terlebih dahulu. Hanya admin yang yst mengakses ystem informasi tersebut.

c. Desain Tabel Pimpinan

Tabel 3 Perancangan Tabel Pimpinan

\begin{tabular}{|c|l|l|c|l|}
\hline NO & \multicolumn{1}{|c|}{$\begin{array}{c}\text { Filed } \\
\text { Name }\end{array}$} & Data Type & $\begin{array}{c}\text { Field } \\
\text { Size }\end{array}$ & Keterangan \\
\hline 1 & Id & Integer & 11 & Id Pimpinan \\
\hline 2 & Nip & Integer & 20 & Nip Pimpinan \\
\hline 3 & Nama & Varchar & 50 & Nama Pimpinan \\
\hline 4 & Alamat & Varchar & 50 & $\begin{array}{l}\text { Alamat } \\
\text { Pimpinan }\end{array}$ \\
\hline 5 & Kelamin & Varchar & 50 & $\begin{array}{l}\text { Kelamin } \\
\text { Pimpinan }\end{array}$ \\
\hline 6 & Kontak & Varchar & 50 & $\begin{array}{l}\text { Kontak } \\
\text { Pimpinan }\end{array}$ \\
\hline 7 & Username & Varchar & 50 & $\begin{array}{l}\text { Username } \\
\text { Pimpinan }\end{array}$ \\
\hline 8 & Password & Varchar & 50 & $\begin{array}{l}\text { Password } \\
\text { Pimpinan }\end{array}$ \\
\hline
\end{tabular}

d. Permohonan Cuti

Tabel 4 Perancangan Tabel Permohonan Cuti

\begin{tabular}{|c|l|l|c|l|}
\hline NO & \multicolumn{1}{|c|}{$\begin{array}{c}\text { Filed } \\
\text { Name }\end{array}$} & Data Type & $\begin{array}{c}\text { Field } \\
\text { Size }\end{array}$ & $\begin{array}{c}\text { Keteranga } \\
\text { n }\end{array}$ \\
\hline 1 & Id & Integer & 11 & Id \\
\hline 2 & Pegawai & Varchar & 20 & Pegawai \\
\hline 3 & Jenis_Cuti & Varchar & 50 & Jenis_Cuti \\
\hline 4 & Tahun & Year & 4 & Tahun \\
\hline 5 & Tanggal & Date & - & Tanggal \\
\hline 6 & Awal_Cuti & Date & - & Awal_Cuti \\
\hline 7 & Sampai_Cuti & Date & - & $\begin{array}{l}\text { Sampai_Cu } \\
\text { ti }\end{array}$ \\
\hline 8 & Status & Integer & 20 & Status \\
\hline 9 & $\begin{array}{l}\text { Alasan } \\
\text { Pegawai }\end{array}$ & Varchar & 50 & $\begin{array}{l}\text { Alasan } \\
\text { Pegawai }\end{array}$ \\
\hline 10 & Pimpinan & Varchar & 50 & Pimpinan \\
\hline 11 & $\begin{array}{l}\text { Alasan_Pimpi } \\
\text { nan }\end{array}$ & Varchar & 50 & $\begin{array}{l}\text { Alasan_Pi } \\
\text { mpinan }\end{array}$ \\
\hline
\end{tabular}

e. Desain Tabel Jenis Cuti

Tabel 5 Perancangan Tabel Jenis Cuti

\begin{tabular}{|l|l|l|c|l|}
\hline NO & \multicolumn{1}{|c|}{$\begin{array}{c}\text { Filed } \\
\text { Name }\end{array}$} & Data Type & $\begin{array}{c}\text { Field } \\
\text { Size }\end{array}$ & Keteranga \\
\hline 1. & Id & Integer & 11 & Id Pegawai \\
\hline 2. & Keterangan & Varchar & 50 & $\begin{array}{l}\text { Keterangan } \\
\text { cuti }\end{array}$ \\
\hline
\end{tabular}

f. Desain Tabel Setting Cuti

Tabel 6 Perancangan Tabel Setting Cuti

\begin{tabular}{|l|l|l|c|l|}
\hline NO & \multicolumn{1}{|c|}{$\begin{array}{c}\text { Filed } \\
\text { Name }\end{array}$} & Data Type & $\begin{array}{c}\text { Field } \\
\text { Size }\end{array}$ & $\begin{array}{c}\text { Keteranga } \\
\text { n }\end{array}$ \\
\hline 1. & Id & Integer & 11 & Id \\
\hline 2. & Jenis & Integer & 11 & Jenis Cuti \\
\hline 3. & Tahun & Year & 4 & Tahun Cuti \\
\hline
\end{tabular}

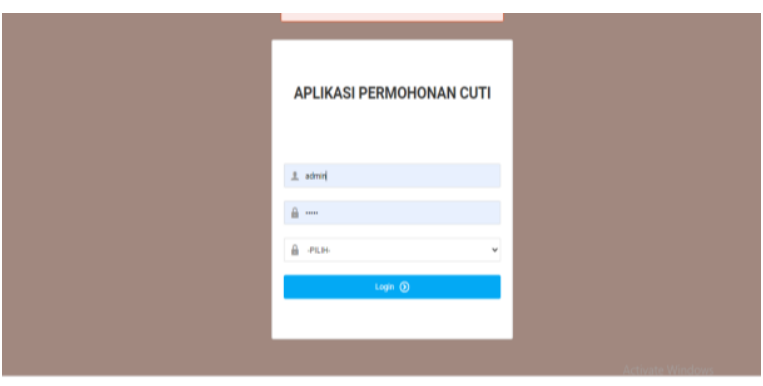

Gambar 6. Form Login Admin

\subsection{Form Utama Admin}

Pada form menu utama, ada beberapa sub menu diantaranya Dashboard, User: Pimpinan dan Pegawai, Jenis Cuti, Setting Cuti, Data Pegawai Cuti, Ganti Password, lalu disertai dengan logout yang digunakan jika user akan keluar dari sistem.

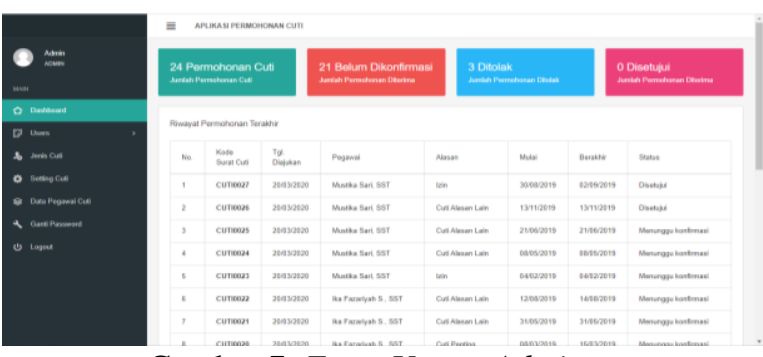

Gambar 7. Form Utama Admin

\subsection{Form Data Pegawai}

Pada form data pegawai, admin dapat menambahkan data pegawai, mengedit data pegawai, melihat detil data pegawai dan dapat menghapus data pegawai.

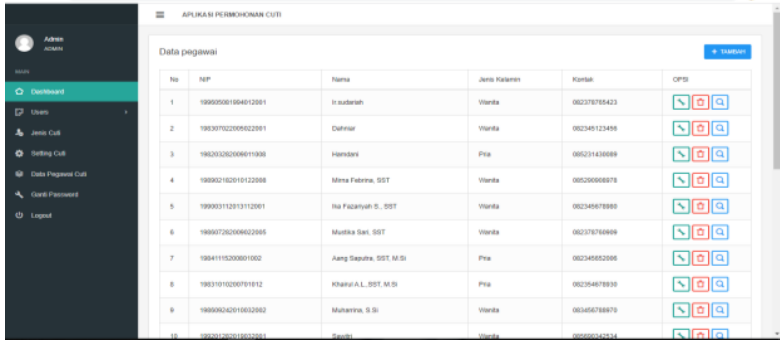

Gambar 8. Form Data Pegawai

\subsection{Form Data Cuti Pegawai}

Diterima Redaksi : 12-03-2021 | Selesai Revisi : 29-03-2021 | Diterbitkan Online : 01-04-2021 
Pada form data Cuti pegawai, admin hanya dapat melihat data cuti pegawai yang sudah mengajukan cuti dan dikonfirmasi oleh pimpinan.

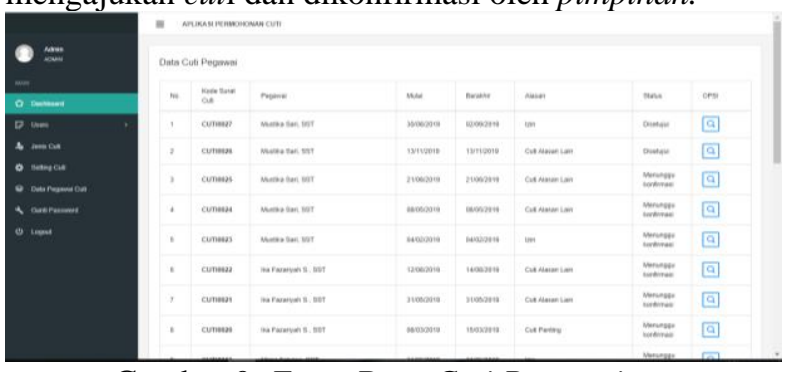

Gambar 9. Form Data Cuti Pegawai

\subsection{Form Login pegawai}

Sebelum menjalankan program, terlebih dahulu masuk ke form login. Pada form login Pegawai harus mengisikan username dan password terlebih dahulu yang sudah didaftarkan oleh admin terlebih dahulu. Hanya Pegawai yang bisa mengakses sistem informasi tersebut.

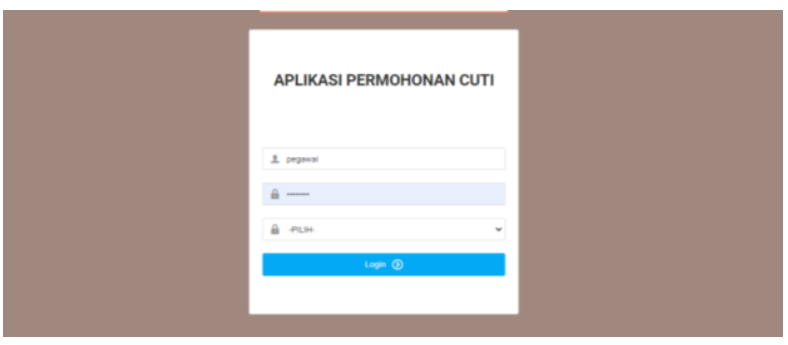

Gambar 10. Form Login Pegawai

\subsection{Form Utama Pegawai}

Pada form menu utama, ada beberapa sub menu diantaranya Dashboard, Permohonan Cuti: Cuti Tahunan dan Cuti "Alasan Lain, Data Cuti Tahunan, Sisa Cuti, Ganti Password, lalu disertai dengan logout yang digunakan jika user akan keluar dari sistem.

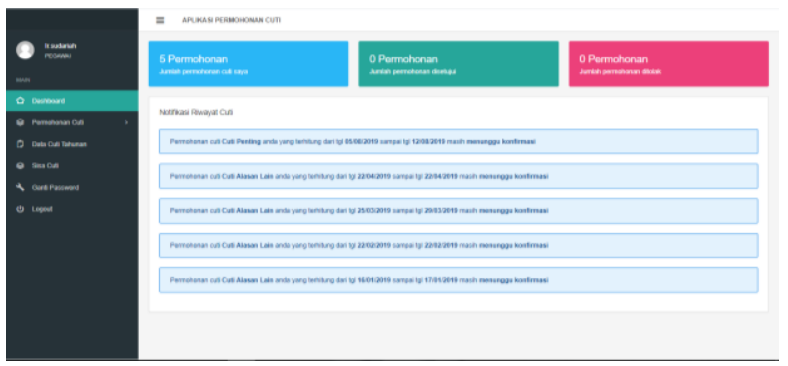

Gambar 11. Form Utama Pegawai

\subsection{Form Permohonan Cuti}

Pada form permohonan cuti, pegawai memilih jenis cuti, memasukkan tanggal mulai cuti, memasukkan tanggal selesai cuti, dan memasukkan alasan cuti, kemudian akan diajukan ke pimpinan.

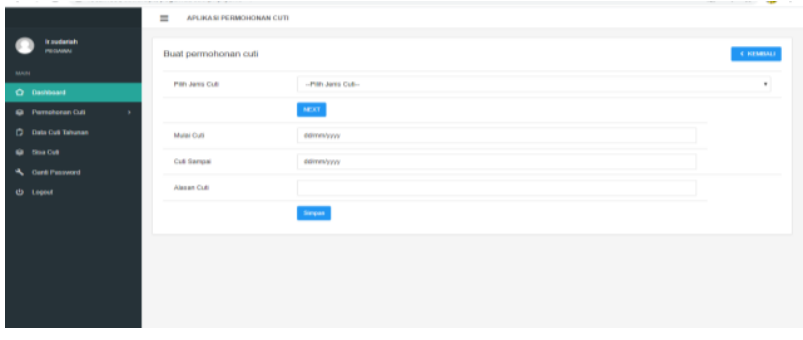

Gambar 12. Form Permohonan Cuti

\subsection{Form Data Permohonan Cuti}

Pada form Data permohonan cuti, pegawai dapat melihat data permohonannya yang disetujui maupun ditolak oleh pimpinan.
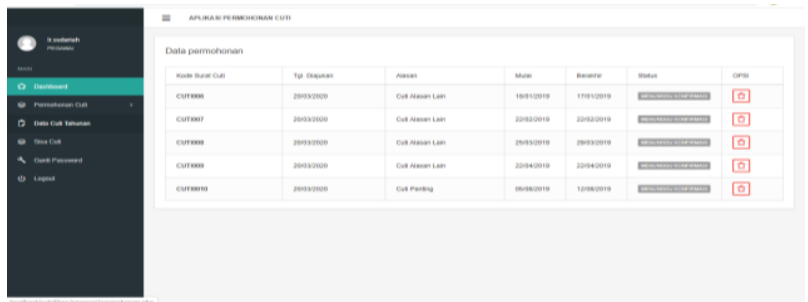

Gambar 13. Form Data Permohonan Cuti

\subsection{Form Formulir Permintaan Dan Pemberian Cuti \\ Pegawai Dapat mencetak Formulir} Permintaan Dan Pemberian Cuti setelah cuti disetujui oleh pimpinan.

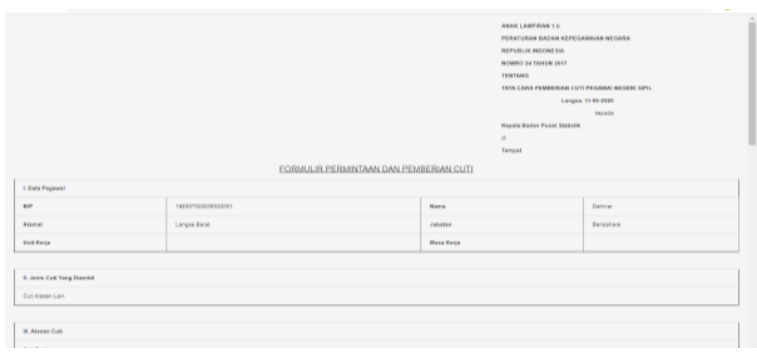

\section{Gambar 14 Form Formulir Permintaan Dan Pemberian Cuti}

\subsection{Form Login Pimpinan}

Sebelum menjalankan program, terlebih dahulu masuk ke form login. Pada form login Pimpinan harus mengisikan username dan password terlebih dahulu. Hanya Pimpinan yang bisa mengakses sistem informasi tersebut.

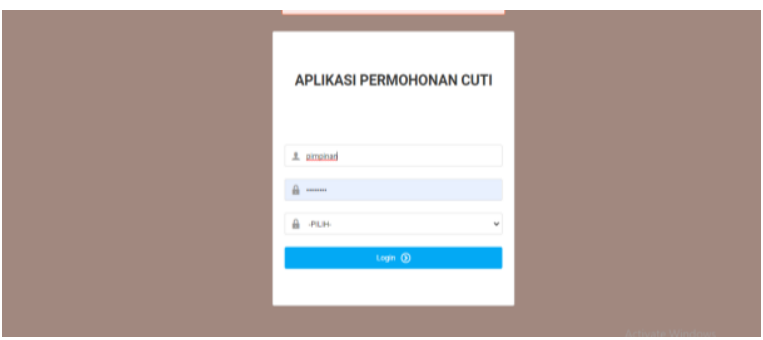




\section{Gambar 15. Form Login Pimpinan}

\subsection{Form Menu Utama Pimpinan}

Pada form menu utama, ada beberapa sub menu diantaranya Dashboard, Pegawai, Permohonan Cuti, Ganti Password, lalu disertai dengan logout yang digunakan jika user akan keluar dari sistem.
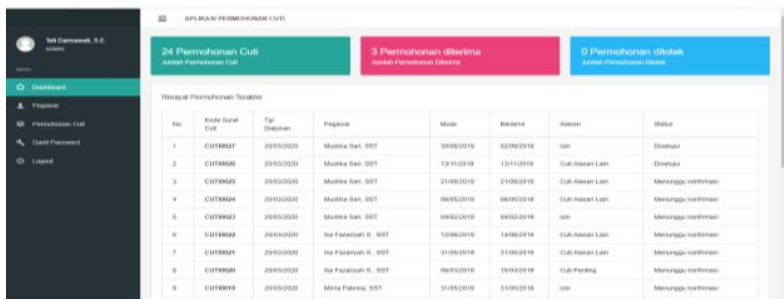

Gambar 16. Form Menu Utama Pimpinan

\subsection{Form Data Pegawai}

Pada form data pegawai, pimpinan hanya dapat melihat data pegawai yang sudah dimasukkan oleh admin.
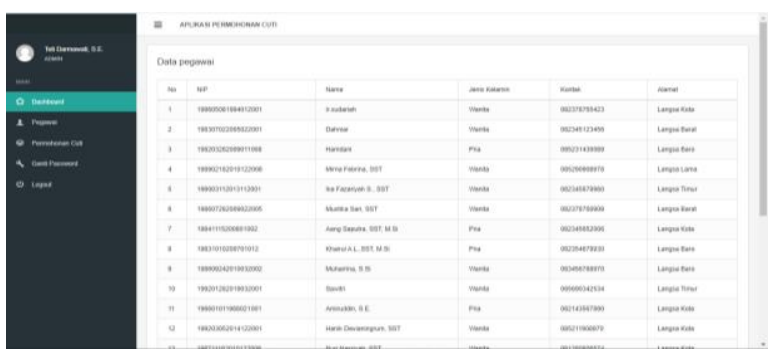

Gambar 17. Form Data Peagawai

\subsection{Form Data Permohonan Cuti}

Pada form Data permohonan cuti, pimpinan dapat menyetujui dan menolak pegawai yang melakukan permohoan cuti.
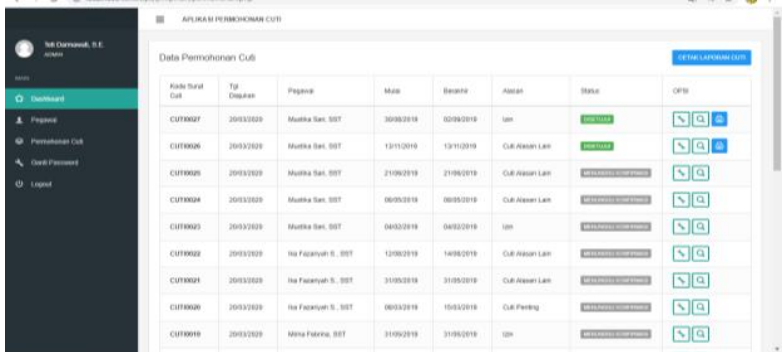

Gambar 18. Form Data Permohonan Cuti

\subsection{Cetak Laporan Cuti Pegawai}

Pada Form Cetak Laporan Cuti Pegawai, pimpinan dapat mencetak laporan cuti pegawai.

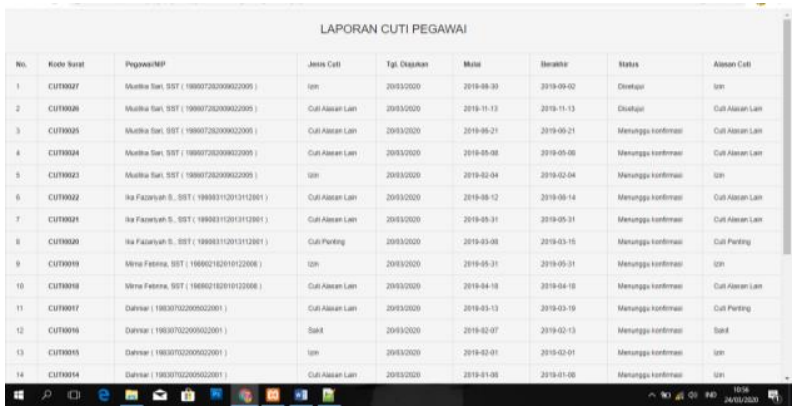

Gambar 19. Form Cetak Laporan Cuti Pegawai

\section{Kesimpulan}

1. Sistem Informasi Cuti Pegawai ini di buat agar Memudahkan dalam mencatat Pegawai yang cuti.

2. Penggunaan sistem informasi cuti pegawai dapat dilakukan oleh pegawai yang ingin mengajukan cuti ke pimpinan. Pimpinan dapat menyetujui cuti yang diajukan, pimpinan juga dapat mencetak laporan cuti pegawai.

3. Perancangan pada sistem ini dibuat untuk membantu menggunakan DFD untuk membantu memahami sistem yang akan dibuat, serta desain database pada sistem ini menggunakan ERD untuk menentukan relasi antar tabel.

\section{Daftar Rujukan}

[1] Arismanto, B., \& Rahmadhani, S. (2019). Pengembangan Sistem Penerimaan Mahasiswa Baru pada STIES Imam Asy Syafii Pekanbaru. Jurnal IntraTech, 3(1), 57-72

[2] Nazwita, Siti, R. (2017). Analisis Sistem Keamanan Web Server Dan Database Server Menggunakan Suricata. Seminar Nasional Teknologi Informasi, Komunikasi Dan Industri (SNTIKI) 9, 308-317.

[3] Ramadhani, S., Saide, S., \& Indrajit, R. E. (2018). Improving creativity of graphic design for deaf students using contextual teaching learning method (CTL). ACM International Conference Proceeding Series, 136140.https://doi.org/10.1145/3206098.32061 28

[4] Negara Badan Kepegawaian Tata Cara Pemberian Cuti Pegawai Negeri Sipil [Book]. Jakarta : Republik Indonesia, 2017 